Relations industrielles

Industrial Relations

\title{
Biases Against Labour Unions in School Textbooks
}

\section{Robert Knoop et Patrick Babin}

Volume 33, numéro 4, 1978

URI : https://id.erudit.org/iderudit/028918ar

DOI : https://doi.org/10.7202/028918ar

Aller au sommaire du numéro

Éditeur(s)

Département des relations industrielles de l'Université Laval

ISSN

0034-379X (imprimé)

1703-8138 (numérique)

Découvrir la revue

Citer cet article

Knoop, R. \& Babin, P. (1978). Biases Against Labour Unions in School Textbooks. Relations industrielles / Industrial Relations, 33(4), 702-705.

https://doi.org/10.7202/028918ar

Tous droits réservés @ C Département des relations industrielles de l'Universite Laval, 1978
Ce document est protégé par la loi sur le droit d'auteur. L'utilisation des services d'Érudit (y compris la reproduction) est assujettie à sa politique d'utilisation que vous pouvez consulter en ligne.

https://apropos.erudit.org/fr/usagers/politique-dutilisation/ 
à un travailleur pour frais de voyage ou frais de subsistance pourront désormais être déduites de son revenu imposable.

La question de la transférabilité des avantages sociaux et des contributions à un régime de pension est relativement complexe. Sur ce point, on a fortement et souvent souligné le problème des travailleurs du Québec qui vont œuvrer dans une autre province ou de ceux des autres provinces qui viennent travailler au Québec; pourtant le problème de la transférabilité n'existe pas qu'entre le Québec et les autres provinces, et le groupe de travail que je mentionnais plus haut considère ce problème comme un des plus importants à analyser. Pour ce qui est du Québec, un accord de réciprocité a été signé récemment par une de vos grandes unions et l'Office de la construction du Québec. On ne voit pas pourquoi de tels accords de réciprocité ne pourraient se négocier par les autres unions pour les autres métiers.

Finalement, il y a les divers programmes des gouvernements, fédéraux et provinciaux, pour encourager la mobilité des travailleurs; mais plusieurs soutiennent qu'ils ne sont pas adaptés aux travailleurs de la construction. Ces programmes soulèvent aussi la question de l'incitation à la mobilité. Tous les programmes gouvernementaux, l'assurancechômage y compris, devraient être analysés simultanément et ajustés les uns par rapport aux autres pour s'assurer qu'il y a plus d'avantages à se déplacer pour travailler qu'à recevoir tout simplement des prestations d'assurance-chômage. Ces questions et plusieurs autres de même nature feront sûrement l'objet des travaux et des analyses du Groupe national de travail sur la mobilité des travailleurs de la construction. Nous espérons tous qu'ils proposeront des recommandations utiles.

\title{
BIASES AGAINST LABOUR UNIONS IN SCHOOL TEXTBOOKS
}

\author{
Robert KNOOP and Patrick Babin
}

Public attitudes towards labour unions are developed, in part, during the formal educational process in both elementary and secondary schools.

* KNOOP, R., Faculty of Commerce and Administration, Concordia University,

** BABIN, P., Faculty of Education, University of Ottawa, Ottawa.

** This research project was funded under contract by the Ministry of Education, Ontario. A copy of the complete report entitled Bias in Textbooks Regarding the Aged, Labour Unionists, and Political Minorities can be obtained from the Ontario Ministry of Education, Toronto. 
If Canadians are to develop an objective and constructive view of the union movement and of the day-to-day activities of labour unions, then the cause of unionism as represented in school textbooks must influence the attitude of Canadian youths during their formative years. The purpose of this research was to investigate the extent and nature of biases against labour unions in school texts. The following is a brief synopsis of the methodology employed and of the findings of a more comprehensive report submitted to the Ontario Ministry of Education.

\section{METHODOLOGY}

The research instrument designed to evaluate textbooks for biases consisted of a provisionary checklist compiled from relevant criteria found in the literature.

Part of the format of the checklist and the "yes-no-not applicable» answer mode to a variety of questions was selected from the National Education Association's "Checklist for Selecting and Evaluating U.S. History Textbooks» (1973). Criteria-content for the biases investigated was based on the following publications: «Rating Sheet for the Evaluation of Materials in Reading ", California State Department of Education (1973) ; Billington's «Bias in History Textbooks » (1966) ; Hodgetts' What Culture? What Heritage? (1969); "How Fair Are Your Children's Textbooks», National Education Association; Joyce's «Minorities in Primary-Grade Social Studies Textbooks: A Progress Report» (1973); Textbook Analysis Nova Scotia, Nova Scotia Human Rights Commission (1974); McDiarmid and Pratt, Teaching Prejudice (1971); Dunfee, «Contributing Ethnic Bias in Instructional Materials: Comment and Bibliography (1974).

The content items were then ordered, condensed, combined, and phrased in question form. In this way, a set of nine questions was developed. These were subsequently given to the Directors of Education of four major labour unions for evaluation and constructive criticism. The questions were then amended to include the suggestions from these union officials.

Over a time span of six months, 211 readers were employed to evaluate 1,719 elementary and secondary school textbooks, or $97 \%$ of the authorized texts. An effort was made to appoint readers representing a cross-section of the population: union members, retired persons, workers, employees, housewives, students and teachers. Texts found to contain bias on first reading were reread by three other evaluators to reduce the chance of incurring misplaced value judgements, irrelevancies, personal opinions of readers, and similar items.

\section{FINDINGS AND DISCUSSION}

Of the textbooks evaluated, 56, or 3.3 per cent, of the texts sampled contained at least one strong biased statement. Intermediate texts, those of grades nine to eleven, accounted for approximately half of the biases, 
while texts in the Senior Division, grades twelve and thirteen, accounted for the other half. No biases were reported for the elementary grades. History and geography texts contained two-thirds of all biases found; the others were dispersed among economics, commercial, and guidance texts.

Half of the biases reported were due to omission: authors of texts neglected to give credit to labour unions for material and social benefits (such as minimum wages, better working conditions, pensions, paid holidays) and did not give fair representation to the history and nature of the labour movement when, in the opinion of the evaluator, the content of the text warranted their inclusion.

Negative statements about unions accounted for the other biases. Unionists were blamed, by open mention or implication, for «the faltering economy», "trouble in the industry», «higher prices», "slow growth", "retardation of technological advances", and "promotion of inefficiency». Unfavourable mention and open or implied criticism was made of union dues, strikes, closed shop, picket lines, seniority provisions, union bosses, and other such terms.

The findings suggest that most authors, publishers, and textbook evaluation committees are simply unaware of the contributions and achievements of labour unions. Not only does it take enlightened, aware, and universally educated authors to produce comprehensive and unbiased textbooks, but it also requires an effort on the part of Canada's labour unions to make their cause known to the public, to provide information to, and communicate with, the public. Channels of information-input have to be provided to ensure fair and adequate representation of labour unions in school textbooks.

\section{REFERENCES}

BILlington, R. A., «Bias in History Textbooks», Educational Digest, Vol. 31, No. 8, 1966.

California State Department of Education, «Rating Sheet for the Evaluation of Materials in Reading», Los Angeles, Cal., 1973.

DUNFEE, M., "Contributing Ethnic Bias in Instructional Materials: Comment and Bibliography », Association for Supervision and Curriculum Development, New York, 1974.

HODGETTS, A. B., What Culture, What Heritage : A Study of Civic Education in Canada, Toronto, Institute for Studies in Education, 1968.

JOYCE, W. W., «Minorities in Primary-Grade Social Studies Textbooks: A Progress Report», Social Education, March 1973.

McDIARMID, G. and D. PRATT, Teaching Prejudice, A Content Analysis of Social Studies Textbooks Authorized for Use in Ontario: A Report to the Ontario Human Rights Commission, Ontario Institute for Studies in Education Series, Curriculum Series No. 12, Toronto, 1971. 
National Education Association, «Checklist for Selecting and Evaluating U. S. History Textbooks», N.E.A., 1973.

National Education Association, «How Fair Are Your Children's Textbooks?», N.E.A., Publication 385-11706, n.d.

Nova Scotia Human Rights Commission, Textbooks Analysis Nova Scotia, Halifax, 1974.

\section{DIALOGUE}

\section{CAPITAL ET TRAVAIL}

La recension de l'ouvrage Capital et travail de Victor Levant préparée par Jean Boivin et publiée dans R.I. vol 33, no 2 a donné lieu à une réaction. Respectant le désir de l'auteur, nous publions dans son intégrité la lettre qu'il nous a adressée. Nous publions de plus les remarques des professeurs Laperrière et Noumoff ainsi que la réplique de Jean Boivin.

Cher Monsieur,

C'est avec plaisir que j'ai pris connaissance de la critique du livre Capital \& Travail publié par votre revue. Cependant, j'ai été frappé par son ton, son caractère et son contenu.

Je présume que vos lecteurs serieux réalisent que l'injure, l'insinuation et l'attaque personnelle sont des pauvres substituts pour des arguments logiques, des opinions rationnelles ou des faits révélateurs.

Ce que me concerne sont les inexactitudes concernant le contenu du volume. Pour illustré mon point, voyons, comme exemple, ces lignes de $\mathbf{M}$. Jean Boivin:

«Il (Victor Levant) passe cependant sous silence le militantisme des syndicats industriels du COI ainsi que d'autres conflits comme ceux des employés du rail, des débardeurs, etc. pour mieux vendre l'idée que, par définition, le syndicalisme international ne peut que pratiquer l'Aplaventrisme devant le Capital. »

Premièrement, je parle des syndicats industriels et militants du COI: les Mineurs unis d'Amérique aux pages 20-32, 118, 180 et 192; les Ouvriers unis du textile d'Amérique aux pages 192, 203 et 220; 1'Union internationale des ouvriers de la mine, du laminage et de la fonderie aux pages 176, 192, 193 et 213 ; les Travailleurs unis de l'automobile d'Amerique aux pages 192 et 203 ; et le Comité organisateur des travailleurs de l'acier à la page 192. En fait je souligne que ces syndicats industriels était expulsés du COI en 1939 précisément à cause de leur militantisme.

Deuxièmement, j'avance nulle part l'idée que, par définition, les syndicats internationals ne peut que pratiquer l'aplaventrisme devant le Capital. J'analyse le mouvement syndical selon son idéologie et sa pratique, et pas selon le lieu des 